The $5^{\text {th }}$ International Conference on Family Business and Entrepreneurship

\title{
CAPITAL STRUCTURE, LIQUIDITY, AND FIRM SIZE IMPACT ON PROFITABILITY OF MINING INDUSTRY IN INDONESIA
}

\author{
Chandra Setiawan ${ }^{1 *}$, Nemísia Freitas de Jesus Pereira ${ }^{2}$ \\ ${ }^{1,2,3}$ Faculty of Business, President University, Corresponding author: chandra@ president.ac.id
}

\begin{abstract}
:
The aim of this research is specifically for measuring the impact of capital structure, liquidity, and firm size on mining industry profitability in Indonesia, both partially and simultaneously. There are five independent variables within this study that are examined by descriptive statistical analysis, classical assumption test, multiple linear regression, and hypothesis testing. In order to select the observation data, purposive sampling method and panel data were used. Adopting quantitative research, there are 119 observation data from 17 samples within the period of 2013 to 2019. Financial ratios used in this study are Debt-to-equity Ratio, Short-term Debt to Asset ratio, Long-term Debt to Asset ratio, Current Ratio, Firm Size, and Return on Equity. DER, STDA, and LTDA are used as the measurement for capital structure, CR as the proxy of liquidity, and FIRMSIZE. Meanwhile, the proxy of profitability is Return on Equity (ROE) which is the dependent variable in this study. The findings of the study reveal that DER, LTDA, and Firm Size all have a significant impact on ROE. On the other hands, STDA and CR do not have a significant effect toward ROE. The most significant independent variable toward ROE is DER.
\end{abstract}

Keywords: Capital Structure, Liquidity, Firm Size, Profitability, Return On Equity, Mining Industry

\section{Introduction}

For a long time, the mining industry has been Indonesia's primary source of revenue. According to Statistics Indonesia (BPS), mining is an economic activity for extracting and preparing mineral in the form of solid, liquid, and gas for further processing. The operation of mining activities is carried out either above (open mining) or below ground (closed mining) including the excavating, scraping and mining of solid, liquid, or gas formed minerals. These products include crude oil, natural gas, coal, iron sand, extract of tin, nickel ore, bauxite, compound of copper, gold, silver, and manganese (Manullang \& Hutabarat, 2020).

Ekspor Indonesia Tahun 2019

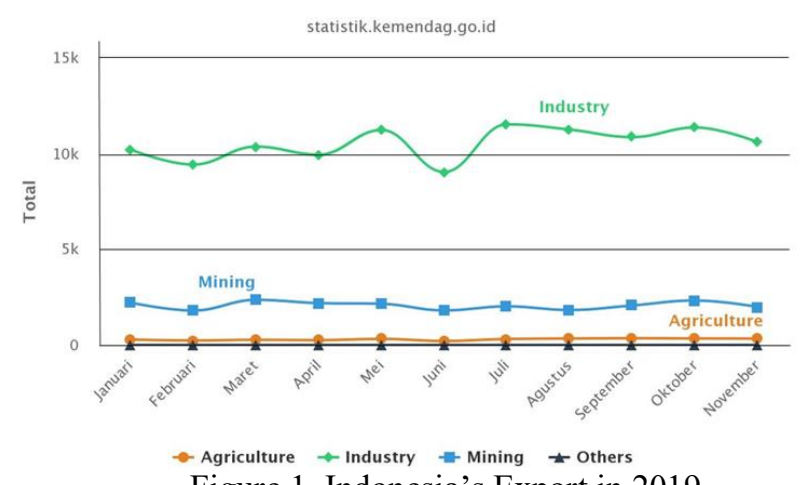

Figure 1. Indonesia's Export in 2019

(Source: Statistics Indonesia (BPS), 2019)

361

(C) 2021. The $5^{\text {th }}$ International Conference on Family Business and Entrepreneurship. 
Based on the above figure on Indonesia's export in 2019, it can be seen that mining industry has made greater export contributions compared to agriculture as Indonesia's main sector.

The Mining Law was portrayed as heralding the start of a new phase of greater certainty for investors in Indonesia's mining industry. However, a decade after its enactment, it has become clear that the Indonesian mining sector's inconsistent policies and regulations continue to hinder investment. These policy uncertainties have caused a number of foreign miners to sell their operations in Indonesia to local stakeholders in recent years, as well as deterring new foreign investment. In particular, it has become clear that the government has had a difficult time for balancing investor's interests with the goal of maintaining a reasonable share of the wealth produced for the good of Indonesia (PwC Indonesia, 2019).

For an enterprising company, productivity is very important. It is through profitability that buyers are willing to buy the shares of the company due to increased reputation and if the demand for its securities increases the prices of the shares, the value of the company increases (Niresh, 2012).

Profitability enables an enterprise to withstand negative economic shocks and enhances the firm's stability. Profitability also maximizes shareholder utility by means of dividends and increased firm value and stakeholder interest through corporate social responsibility (Bhutta \& Hasan, 2013). Return on assets, return on equity, and gross margin are all examples of profitability metrics that have been identified in various previous studies. Two of the most crucial parameters for determining how well a corporate is managing the resources entrusted to it are return on equity (ROE) and return on assets (ROA) (Daryanto \& Samidi, 2018). ROA measures how effectively an organization uses its assets to generate revenue, while ROE measures how effectively an organization uses its equity, or capital, to generate revenue, and ROE can always be applicable to any particular industry or service (Ahmad, Abdullah, \& Roslan, 2012).

There can be circumstances when a company's equity is negative. This normally happens when a company has been losing money for a long time and has had to borrow money to remain in business; as a result, liabilities would be greater than assets (Mirza \& Javed, 2013). Thus, since ROE is not asset-dependent, it is suitable for assessing the profitability of Indonesia's mining companies, which have been making losses in recent years.

There are several factors which could influence a company's profitability, and one is the capital structure. As a consequence, the correlation between capital structure decisions and a company's profitability has got a lot of interest in recent decades (Ahmad, Abdullah, \& Roslan, 2012). According to Suardi and Noor (2015), capital structure is essentially a composition of debt and equity funding, taking into account the necessary debt return rates as well as equity investors. Over the long term, a firm's capital structure is a compound of debt and equity. In other words, what percentage of the cash flow of the company goes to the investors and what percentage the shareholders get.

In addition, the importance of liquidity to company performance may lead to the conclusion that it also influences the level of business profitability. This concern was also one of the topics of several theoretical and empirical studies conducted (Zygmunt, 2013; Salim \& Wahyuni, 2019; Astita \& Kalam, 2013). Liquidity is an entity's ability to take advantage of its existing assets to settle up its current liabilities. Liquidity will reduce the company's current costs to the business. High liquidity will also reflect the high competence of the company to settle its liabilities, so it will signal the company is in good health (Birjandi, Dehmolaee, Sheikh, \& Sana, 2021). If the company's current loans can be repaid, the company can also cover the interest expense on the loan. This may indicate that the finances of the company are or are not in good condition. Current ratio may be used to measure current assets excess over current liabilities (Restianti \& Agustina, 2018). Accordingly, this study sheds light concerning the impact of capital structure, liquidity and firm size on corporate profitability. Because of data and time limitations, the researcher focuses only on Indonesian companies, particularly in the mining sector. The respective companies are also only chosen from the ones classified on IDX.

\section{Literature Review}

\section{Return on Equity}

Firm performance reflects the way firms manage their resources effectively (Wassie, 2020). Moreover, company's financial performance is vitally important for creditors, stakeholders and the economy as a whole (Mirza \& Javed, 2013). Profitability is a company's most common financial performance indicator and it would help boost employee salaries, deliver better quality products and have more environmentally friendly units of output (Daryanto \& Samidi, 2018; Mirza \& Javed, 2013). Return on equity is a significant 362 
proportion for investors to consider their earnings. ROE examines how a company can make effective use of investors' capital to generate profits and grow the business (Daryanto \& Samidi, 2018). Moreover, the results of ROE calculations are highly influenced by the profitability of the company, so the higher the results obtained by calculating this ratio, the better the position company will be shown (Brigham ${ }^{\ell}$ Houston, 2019).

$$
\text { ROE }=(\text { Net Income }: \text { Shareholders' } E) \times 100
$$

\section{Debt-to-equity Ratio}

In general, a firm's capital process can be described as a unique combination of debt and equity that used to fund its activities. The right compound of debt and equity will increase the overall market value of a company (Rahmawati, 2020). One of the strategy companies implementing to boost their financial performance is the use of different levels of equity and debt (Leonard \& Mwasa, 2014; Setiawanta et al., 2020). DER was chosen as one of the proxy of capital structure in this research because managers in a business need to take the debt equity ratio as a warning, since high leverage means a higher risk of lowquality bankruptcy and the debt structure can be considered a signal to the market (Chowdhury \& Chowdhury, 2010; Chandra, Junaedi, Wijaya, \& Ng, 2021). When the resulting, DER ratio is getting higher, then it will show even higher financing provided for the company by shareholders and if it gets lower the results of this ratio will be the capability of the company to pay long-term obligations. The company's overall debt amount must be the same with its own capital or, in other words, the maximum debt amount is 100\% (Higgins, Koski, \& Mitton, 2016).

$$
\text { DER = Total debit: } \text { Total Equity }
$$

\section{Short Term Debt to Total Asset}

The ratio of short-term debt to total asset could be used in checking the effect of short-term debt financing on a company's performance (Habib, Khan, \& Wazir, 2016). The issuance of short-term debts is viewed as a positive indicator of a company's low credit risk; as a result, companies with the best credit ratings tend to issue short-term debts due to low refinancing risks. Furthermore, the use of short-term debts improves the availability of external funding and encourages businesses to improve their financial efficiency (Horne \& Wachowicz, 2008).

$$
\text { STDA = Short }- \text { term debit: } \text { Total Equity }
$$

\section{Long Term Debt to Total Asset}

According to Horne \& Wachowicz (2008), LTDA means liabilities to be repaid more than one year later in which it includes bonds and long-term lending. By measuring the percentage of a company's assets that are actually financed by debt, the long-term debt to asset ratio gives a clear picture of how leveraged it is. If a company's long-term debt to asset ratio is steadily growing, its growth model or strategy can be deemed too risky or unsustainable over time (Rehman et al., 2012). The formula for LTDA as stated by (Horne \& Wachowicz, 2008) is:

$$
\text { LTDA = Long }- \text { term debit:Total Asset }
$$

\section{Current Ratio}

Liquidity is an important measure for each company. It shows when to pay the current business obligations including short-term, but maturing, operational and financial expenses (Saleem \& Rehman, 2011). A proportion that indicates a company's capacity to resolve short term debt owed or to assess the company's in finance potential and meet obligations when billed is known as the liquidity ratio. These ratios illustrate the competence of the company to fulfill short-term liabilities. They can be calculated using work capital information sources, in example posts of current assets and current debts (Ginting \& Nasution, 2020; Pranowo \& Achsani, 2010).Current ratio as the liquidity ratio shows the current assets collateral rate of the 
debt. The more liquid CR the better it is, but too liquid CR can also endanger the companies, so a company needs to keep its CR stable to reduce the likelihood of bankruptcy (Brigham \& Houston, 2019).

$$
\text { CR }=(\text { Current asset }: \text { current debt }) \times 100
$$

Firm Size

The size of a firm demonstrates a necessary role for determining the type of relationship that a company enjoys inside and outside its operating environment (Mercangöz, 2021). A company which is more likely to have a greater influence on its stakeholders when it is a bigger company (Babalola, 2013; Batra \& Kalia, 2016). The size of a firm is measured in terms of its size, the capability and involvement in the stock market and other financial markets external funding sources (Purwanto \& Agustin, 2017; Fathinah \& Setiawan, 2020). The higher the total assets showing the company's own assets indicated to the investors that the safer it is to invest in the business (Higgins et al., 2016).

$$
\text { Firm Size }=\text { Log Total Assets }
$$

\section{Research Method}

This study is using quantitative method for examining the impact of capital structure, liquidity, and firm size toward profitability of mining companies. This approach was chosen because it focuses on calculation to get the input data in reaching the output. Hence, there are several instruments used to process the data obtained from the selected companies' financial statements, journals, websites, and books. Moreover, due to the needs of this study, two statistic measures in the phase of data processing, Eviews Enterprise version 10 and Microsoft Excel 2013 were used among other available statistical tools. Furthermore, secondary data is used as the method to collect data for this study. Secondary data is the suitable method for this study due to all important data for this study are in form of financial report of companies that belong to the mining industry in Indonesia. Finally, there are 17 selected samples out of 26 populations of companies included in mining industry in the period of 2013 to 2019 in Indonesia and the data observations in this study in total are 119 data observations.

This study used Multiple Regression Analysis, which is a useful way in estimating and predicting the mean population value for independent variable for dependent variable. Multiple regression modeling is widely used in the evaluation of financial factors and activities for forecasting (Schwert, 2010). Since there are five independent variables in this analysis, multiple regression is used. The five variables are debt equity ratio (X1), short term debt to asset ratio (X2), long term debt to asset ratio (X3), current ratio (X4), and firm size (X5). Meanwhile, ROE was set as the dependent variable in this study. The multiple regression can be formulated as follows:

$$
Y=a+\beta 1 X 1+\beta 2 X 2+\beta 3 X 3+\beta 4 X 4+\beta 5 X 5+\varepsilon
$$

The result of the partial regression coefficient which represents the measurement of dependent variable per unit change in the particular independent variable is becoming an important role as a basic analysis for this study. This study also applied T-Test in order to figure out the influence among independent and dependent variable and to know number of T-Statistic probabilities of each independent variable. Through T-test, it was possible to determine if there is any partial effect between both independent and dependent variables. F-Test is utilized to evaluate how independent variables influence dependent variable substantially at the same time and adjusted R2 was used for the analysis in terms of the determination coefficient.

Table 1. Multiple Regression Analysis Result

\begin{tabular}{lcccc}
\hline \multicolumn{1}{c}{ Variable } & Coefficient & Std. Error & t-statistic & Prob. \\
\hline C & -0.74368 & 0.303667 & -2.444902 & 0.0159 \\
DER & -0.06563 & 0.016682 & -3.934252 & 0.0001 \\
STDA & 0.2566683 & 0.218775 & 1.173272 & 0.2432 \\
LTDA & -0.033660 & 0.011289 & -2.981762 & 0.0035 \\
CR & 0,011962 & 0.013593 & 0.879988 & 0.3807 \\
FIRMSIZE & 0.048479 & 0.015646 & 3.09898 & 0.0025 \\
\hline
\end{tabular}




\section{Results and Discussion}

\section{The Influence of Debt-to-Equity Ratio toward Profitability}

After conducting several analyses, the researchers found that the probability value is 0.0001 . This means that the previous hypothesis is agreed, implying that debt-to-equity ratio has a significant impact on mining company profitability in Indonesia. Moreover, the debt-to-equity ratio has a negative significant effect on a company's return on equity, as shown by the coefficient regression of -0.0656 . It denotes that the increase of debt-to-equity ratio will lead to the decrease of company's return on equity.

Debt-to-equity Ratio had been examined and it showed a significant negative impact towards Return on Equity. The debt-to-equity ratio indicates how much a firm relies on debt to finance its operations rather than purely funds. In the event of a business downturn, it represents the willingness of shareholder equity to pay all unpaid debts. It is most commonly used to determine how much debt a firm is taking on in order to leverage its cash. However, using the same components such as equity in ROE and DER could be seen as the limitation of this research. Nevertheless, a high debt-to-equity ratio is also correlated with high risk; it indicates that a business has used leverage to fund its expansion.

\section{The Influence of Short-Term Debt to Total Assets toward Profitability}

After conducting several analyses, the researchers found that the probability value is 0.2432 . Therefore, the interpretation is that the hypothesis above is rejected. This means there is an insignificant influence of debtto-equity ratio towards profitability of mining companies in Indonesia and short-term debt to total asset ratio cannot be used for determining profitability of Indonesia's mining companies. This result contradicted the study of Wahyuni (2013), which showed that short term debt to total asset ratio had a significant negative effect on return on equity.

Short Term Debt to Total Asset ratio had been examined and showed the result of a positive insignificant impact toward Return on Equity. When short-term debt has a positive relationship with return on equity, profits rise. However, it has insignificant impact on ROE. Therefore, the scale of the STDA ratio has no control upon the profitability and the size of profitability is unaffected by short-term debt management.

\section{The Influence of Long-Term Debt to Total Assets toward Profitability}

The third hypothesis in this study stated "There is an influence of LTDA on profitability in mining companies of Indonesia". After conducting several analyses, the researchers found that the probability value is 0.0035 . Therefore, the interpretation is that the hypothesis above is accepted. This implies that long-term debt to total asset ratio has a significant impact on mining company's profitability in Indonesia. Furthermore, long term debt to total asset ratio has a negative significant influence to company's return on equity, which is shown by coefficient regression of -0.0337 . This indicates that as the long-term debt-tototal-asset ratio is increasing, the company's return on equity will decrease.

Long Term Debt to Total Asset ratio had been examined and showed the result of a significant negative influence on Return on Equity. By analyzing the percentage of a company's assets that are currently funded through debt, the Long-Term Debt to Assets ratio gives a clear picture of how leveraged it is. If a company's Long-Term Debt to Assets ratio is steadily growing, its growth model or strategy can be deemed too risky or unsustainable over time. The higher the ratio, the more leveraged it is.

\section{The Influence of Current Ratio toward Profitability}

The fourth hypothesis in this research stated "There is an influence of CR on profitability in mining companies of Indonesia". After conducting several analyses, the researchers found that the probability value is 0.3807 . Therefore. This means that the hypothesis above is refuted. This also indicates that debt-to-equity ratio has no significant impact on mining company's profitability in Indonesia. However, current ratio has a positive insignificant influence to the company's return on equity, which is shown by coefficient regression of 0.0120 . It means that as the current ratio rises, the company's return on equity also rises. This means that despite having insignificant impact on profitability, current ratio still positively influences the profitability of Indonesia's mining companies.

Current Ratio had been examined and showed a result of an insignificant positive impact on Return on Equity. Even though the result from the data analysis is indicating the insignificant impact of current ratio on return on equity, companies cannot ignore it completely because when a company's current ratio seems to be very high in comparison to its peer group, it means that management is not making the best use of its 
capital. Therefore, companies need to maximize the current assets on its balance sheet to satisfy its current debt and other payables.

\section{The Influence of Firm Size toward Profitability}

The fifth hypothesis stated within this research is "There is an influence of Firm Size on profitability in mining companies of Indonesia". After conducting several analyses, the researchers found that the probability value is 0.0025 . Therefore, the interpretation is that the hypothesis above is accepted. This implies that long-term debt to total asset ratio has a significant impact on mining company profitability in Indonesia. In addition, the coefficient regression of 0.0485 shows that firm size has a positive significant impact on a company's return on equity. It indicates an increase of firm size will lead to an increase of the company's return on equity.

Firm Size had been examined and showed the result of significant positive impact on Return on Equity. This significant and positive impact means that the larger the company's size value, the better it can explain and forecast increase in profitability. The lower the value of firm size, on the other hand, the more it can clarify and anticipate the decline in profitability.

\section{Simultaneous Influence of All Independent Variables toward Profitability}

According to the sixth hypothesis which stated that there is an influence of debt-to-equity ratio, short term debt to total asset ratio, long term debt to total asset ratio, current ratio, and firm size toward return on equity of the mining companies in Indonesia, F-statistics get a probability value of 0.0000 , which is less than $5 \%$. This value signifies that the dependent variable is determined by all independent variables simultaneously, so the hypothesis is accepted. The simultaneous influence of all independent variables shown through the value of adjusted R-squared can influence return on equity by $20.23 \%$. The remaining $79.77 \%$ were influenced by other variables that are excluded from this research.

Depending on F-test results, Debt-to-equity Ratio, Short Term Debt to Total Asset ratio, Long Term Debt to Total Asset ratio, Current Ratio, and Firm Size have a simultaneous influence on Return on Equity of $20.23 \%$, with the remaining $79.77 \%$ influenced by other factors excluded from this research.

The Most Significant Influence Independent Variable toward Profitability

The most significant effect of independent variables on dependent variable could be ranked by t-statistical analysis results. The higher the t-statistics, the greater the independent variable's effect on the dependent variable, in which it can be sorted out by the probability value of t-statistics. The lower the probability value comes close to 0 , the greater the statistical effects of dependent variable. Following on the level of significance to the dependent variable, independent variable that has the most significant influence is the debt-to-equity ratio with a probability value of 0.0001 and coefficient value of -0.0656 .

According to t-statistics test results which could be used to rank the independent variables by the level of significance toward the dependent variable, Debt-to-equity Ratio comes out for having the most significant impact on Return on Equity with a probability value of 0.0001, followed by Firm Size, and then Long-Term Debt to Total Asset ratio in the third place.

\section{Conclusion and Implications}

There are five independent variables investigated and the results showed that debt-to-equity ratio (DER), long term debt to total asset (LTDA), and firm size (FIRMSIZE) have partially significant influence on return on equity (ROE). Meanwhile, short term debt to total asset (STDA) and current ratio (CR) partially showed no significant influence on return on equity.

Profitability allows a company to endure unfavorable financial crises while also increasing its safety. Profitability also increases value for shareholders and stakeholder interest through dividends and increasing company value through corporate social responsibility. In the long-term, capital structure and liquidity correlation with company profitability have piqued interest, as it is critical to assess the debt and equity financing proportion. This reflects the necessary debt return rates along with equity investors, as well as the company's ability to use current resources to settle current liabilities.

\section{References}

Ahmad, Z., Abdullah, N. M., \& Roslan, S. (2012). Capital Structure Effect on Firms Performance: Focusing on Consumers and Industrials Sectors on Malaysian Firms. International Review of Business Researxh Papers, 137 - 155. 
Astita, R., \& Kalam, R. (2013). The Effect of Liquidity and Capital Structure on Profitability (Case Study in Food \& Beverage Sector Manufacturing Companies Listed on the Indonesia Stock Exchange 2007-2012 Period) [translated to English by researcher]. Jurnal Riset Akuntansi, 87 - 105.

Babalola, Y. A. (2013). The Effect of Firm Size on Firms Profitability in Nigeria. Journal of Economics and Sustainable Development, 90 - 94.

Batra, R., \& Kalia, A. (2016). Rethinking and Redefining the Determinants of Corporate Profitability. Global Business Review, 17(4), 921-933.

Bhutta, N. T., \& Hasan, A. (2013). Impact of Firm Specific Factors on Profitability of Firms in Food Sector. Open Journal of Accounting, 19 - 25.

Birjandi, A. K., Dehmolaee, S., Sheikh, R., \& Sana, S. S. (2021). Analysis and Classification of Companies on Tehran Stpck Exchange with Incomplete Information. RAIRO Operations Research, 55, S2709S2726.

Brigham, E., \& Houston, J. (2019). Fundamentals of financial Management 15e. Boston: Cengage Learning, Inc.

Chandra, T., Junaedi, A. T., Wijaya, E., \& Ng, M. (2021). The Impact of Co-structure of Capital, Profitability and Corporate Growth Opportunities on Stock Exchange in Indonesia. Journal of Economic and Administrative Sciences.

Chowdhury, A., \& Chowdhury, S. P. (2010). Impact of Capital Structure on Firm's Value: Evidence from Bangladesh. Business and Economic Horizons, 111 - 122.

Daryanto, W. M., \& Samidi, S. (2018). Measuring the Financial Performance of Enterprises Under Ministry of Energy and Mineral Resources (EMR) an Indonesia Experience. International Journal of Engineering \& Technology, 16 - 23.

Fathinah, H., \& Setiawan, C. (2020). The Effect of Financial Ratios and Firm Size Toward Stock Price of Consumer Goods Industry Listed in the IDX. International Conference on Economics, Management, and Accounting.

Ginting, W. A., \& Nasution, S. A. (2020). Empirical Study: The Effect of Firm Size, Current Ratio, and Total Asset Turnover on Profitability through Return on Equity [translated to English by researcher]. Ekonomi, Keuangan, Investasi dan Syariah, 79 - 85.

Habib, H. J., Khan, F., \& Wazir, D. (2016). Impact of Debt on Profitability of Firms: Evidence from Nonfinancial Sector of Pakistan. City University Research Journal, 70 - 80.

Higgins, R., Koski, J., \& Mitton, T. (2016). Analysis for Financial Management; Eleventh Edition. New York: McGraw-Hill Education.

Horne, J., \& Wachowicz, J. (2008). Fundamentals of Financial Management, 13th Edition. London: Pearson Education.

Leonard, M., \& Mwasa, I. (2014). Capital Structure and Financial Performance in Kenya: Evidence from Firms Listed at the Nairobi Securities Exchange. International Journal of Social Sciences and Entrepreneurship, 1(11), 209 - 223.

Manullang, S. V., \& Hutabarat, F. (2020). Sustainable Growth and Liquidity on Profitability: A Study on Mining Sector Companies Listed at Indonesia Stock Exchange in 2018. Jurnal AKSI (Akuntansi dan Sistem Informasi), 5 (1), 24-29.

Mercangöz, B. (2021). Handbook of Research on Emerging Theories, Models, and Applications of Financial Econometrics. Springer Nature.

Mirza, S. A., \& Javed, A. (2013). Determinants of Financial Performance of a Firm: Case of Pakistani Stock Market. Journal of Economics and International Finance, 43 - 52.

Niresh, J. (2012). Trade-off Between Liquidity \& Profitability: A Study of Selected Manufacturing Firms in Sri Lanka. Journal of Arts, Science \& Commerce, 34 - 40.

Pongrangga, R. A., Dzulkirom, M., \& Saifi, M. (2015). The Effect of Current Ratio, Total Asset Turnover and Debt to Equity Ratio on Return On Equity (Study of Property and Real Estate Sub Sector Companies Listed on the IDX 2011-2014) [translated to English by researcher]. Jurnal Administrasi Bisnis.

Pranowo, K., \& Achsani, N. A. (2010). Determinant of Corporate Financial Distress in an Emerging Market Economy: Empirical Evidence from the Indonesian Stock Exchange 2004-2008. International Research Journal of finance and Economics.

Purwanto, P., \& Agustin, J. (2017). Financial Performance towards Value of Firms in Basic and Chemicals Industry. European Research Studies Journal, XX(2A), 443-460.

Rahmawati, C. H. (2020). The Profitability, Firm's Size, Dividend Payout Ratio and Firm's Value: Capital Structure Intervention. Jurnal Ekonomi Bisnis dan Kewirausahaan (JEBIK), 9(3), 218-235. 
Rehman, W., Fatima, G., \& Ahmad, D. (2012). Impact of Debt Structure on Profitability in Textile Industry of Pakistan. Int. J. Eco. Res., 61 - 70.

Restianti, T., \& Agustina, L. (2018). The Effect of Financial ratios on FInancial Distress conditions in Sub Industrial Sector Company. Accounting Analysis Journal, 25 - 33.

Saleem , Q., \& Rehman, R. U. (2011). Impacts of Liquidity Ratios on Profitability (Case of Oil and Gas Companies of Pakistan). Interdisciplinary Journal of Research in Business, 95 - 98.

Salim, M., \& Wahyuni, E. S. (2019). The Effect of Internal, External Factors on Corporate Performance and Its Impact on Corporate Values in Indonesia Manufacturing Companies in the Automotive Sub Sector and Its Components in 2008-2017. International Journal of Engineering Technologies and Management Research, 6(6).

Schwert, G. W. (2010). Eviews7 User's Guide II. US: Quantitative Micro.

Setiawanta, Y., Utomo, D., Ghozali, D., \& Jumanto, J. (2020). Financial Performance, Exchange Rate, and Firm Value: The Indonesian Public Companies Case. Organizations and Markets in Emerging Economies, 11(2 (22)), 348-366.

Sofie, B. N. (2015). The Effect of Capital Structure and Liquidity on Profitability [translated to English by researcher]. e-Journal Akuntansi Trisakti, 13 - 28.

Suardi, I., \& Noor, K. D. (2015). The Impact of Capital Structure on Financial Performance of the Listed Agriculture Companies in Indonesia. Global Journal of Business and Social Science Review, 9 17.

Wahyuni, S. (2013). The Effect of Capital Structure on Profitability in Manufacturing Companies Listed on the Indonesia Stock Exchange [translated to English by researcher]. Management Analysis Journal.

Wassie, F. (2020). Impacts of Capital Structure: Profitability of Construction Companies in Ethiopia. Journal of Financial Management of Property and Construction, 25(3), 371-386.

Zygmunt, J. (2013). Does Liquidity Impact on Profitability? Conference of Informatics and Management Sciences. Industrial Marketing Management, 9(4), 311-318. 